\title{
Effects on soil characteristics by different management regimes with root sucker generated hybrid aspen (Populus tremula L. $\times$ P. tremul- oides Michx.) on abandoned agricultural land
}

\author{
Rose-Marie Rytter ${ }^{(1)}$, \\ Lars Rytter ${ }^{(2)}$
}

\begin{abstract}
Fast-growing Populus species are becoming frequently used at afforestation of arable land globally and hybrid aspen is promising for short rotation forestry in the northern hemisphere. Knowledge about growth performance of the second-generation plantations, i.e., consisting of root sucker generated shoots after clearcutting of the original stand, is increasing, but less information is available on the effects on soil properties, especially with varying management. We followed the soil effects of three different management regimes, including 4-, 8- and 16-year rotations with thinning measures in the two longer rotations, in root sucker generated hybrid aspen on former agricultural land. The study was performed in a randomized block design and changes in soil variables were estimated by repeated sampling, i.e., at root sucker initiation and after eight years. Concentrations and pools of soil organic carbon (SOC) and soil nutrients, $\mathrm{pH}$ and bulk density were analysed in the 0-15 and 15-30 $\mathrm{cm}$ mineral soil. Common for all management regimes were unchanged SOC and nutrient pools; $\mathrm{pH}$ and bulk density were also unaffected during the study period. Afforestation effects on the vertical distribution of nutrients, i.e., redistribution of $\mathrm{NH}_{4}-\mathrm{N}, \mathrm{K}$ and $\mathrm{Mg}$ from deeper to shallower soil by plant uptake and release through litter decomposition, were observed in all management regimes. A different effect was noted for $\mathrm{NO}_{3}-\mathrm{N}$ where a declining trend was observed. This could indicate a leakage of the ion, but $\mathrm{NO}_{3}-\mathrm{N}$ distributions in soils are variable which makes interpretations difficult. The results suggest that different management strategies have small initial effects on mineral soil characteristics. However, soil changes need to be followed for an extended period to get more information on the long-term impact of afforestation and management of root sucker generated stands.
\end{abstract}

Keywords: Afforestation, Bulk Density, Nutrient Removal, pH, Rotation Time, Soil Organic Carbon (SOC), Soil Nutrients

sequestration in biomass and soil. Their natural habitat covers the entire northern hemisphere and species like European aspen and North American trembling aspen (P. tremula L. and P. tremuloides Michx.) are among the most widespread tree species globally (Rytter et al. 2011). Hybrid aspen is a crossing between those two species and has mainly been bred in Sweden, Finland and Germany (Rytter et al. 2011). The hybrid has shown a high poten-
(1) Rytter Science, Backavägen 16, SE-268 68, Röstånga (Sweden); (2) The Forestry Research Institute of Sweden (Skogforsk), Ekebo 2250, SE-268 90, Svalöv (Sweden)

@ Rose-Marie Rytter (rytter.science@bwm.se)

Received: May 17, 2018 - Accepted: Aug 11, 2018

Citation: Rytter R-M, Rytter L (2018). Effects on soil characteristics by different management regimes with root sucker generated hybrid aspen (Populus tremula $\mathrm{L} . \times P$. tremuloides Michx.) on abandoned agricultural land. iForest 11: 619-627. - doi: 10.3832/ifor2853-011 [online 2018-10-04]

Communicated by: Werther Guidi Nissim tial for biomass production under north European conditions on former agricultural land, reaching 8-10 Mg DM ha ${ }^{-1}$ year $^{-1}$, which is more than most other tree species at northern latitudes (Telenius 1999, Johansson 2013, Rytter et al. 2013). Both parent species and their crossing generate dense root sucker stands after clear cutting, i.e., a second generation. Hybrid aspen may produce 50,000-100,000 shoots ha ${ }^{-1}$ from root suckers in this second generation (Liesebach et al. 1999, McCarthy \& Rytter 2015). Thus, the ability for root sucker sprouting in combination with the high production potential makes hybrid aspen promising for short rotation forestry in the Nordic region. Short rotation forestry with hybrid aspen is a relatively new silvicultural approach in this region and further research is needed on various management, physiological and environmental aspects concerning not only the first-generation plantation, but also the second generation emerging from root suckers (Tullus et al. 2012).

Hybrid aspen is considered a suitable tree species for afforestation of abandoned agricultural land. Growing aspen and pop- 
Tab. 1 - Arable top soil $(0-30 \mathrm{~cm}$ ) origin and textural class (particle sizes $<2 \mathrm{~mm}$ ), cation exchange capacity (CEC) and degree of base saturation (BS) at $\mathrm{pH} 7$ for soils in the region of the experimental site. The Swedish nomenclature is based on clay content and soil particle size (Atterberg 1905). The approximate conversion to the international classification system is shown (Eriksson et al. 1999, FAO 2006). Data on CEC and BS for the region is from Eriksson et al. (2010).

\begin{tabular}{llc}
\hline Property & Nomenclature/Units & Value/Range \\
\hline Sediment & - & Unsorted \\
\hline Origin & - & Glacial \\
\hline Textural class & Swedish nomenclature & Light clay \\
& International nomenclature & Loam \\
\hline $\mathrm{CEC}_{\mathrm{pH} 7}$ & $\mathrm{cmol}_{\mathrm{c}} \mathrm{kg}^{-1} \mathrm{dW}^{-1}$ & $11.0-14.9$ \\
$\mathrm{BS}_{\mathrm{PH} 7}$ & $\%$ & $73-86$ \\
\hline
\end{tabular}

lars on fertile arable sites are known to promote high growth rates (Tullus et al. 2012) and there may be a significant potential for mitigating high atmospheric $\mathrm{CO}_{2}$ levels by sequestering $C$ in biomass and soil (Rytter 2012a). Arable soils contain 50-75\% of their natural (i.e., before the conversion to arable land) ( stocks in general and thus have a capacity to sequester $C$ to recover their original levels (Lal 2008). Site preparation, planting procedure and mechanical weed control can lead to soil disturbance with subsequent initial release of $\mathrm{CO}_{2}$ Studies of afforestation with Populus species suggest that soils at first act as source and later as sinks for C (Hansen 1993, Grigal \& Berguson 1998, Jug et al. 1999, Arevalo et al. 2011). But there are also studies where no decrease in soil organic carbon (SOC) were observed initially (Rytter 2016) Short-rotation forestry implies frequent harvesting intervals and removal of large quantities of biomass including nutrients (Rytter 2002). It is therefore crucial to monitor changes in $\mathrm{pH}$ and plant nutrients, to detect eventual nutrient deficiency or risk of leakage. So far, studies of soil effects at afforestation with hybrid aspen have dealt with first-generation plantations (Lutter et al. 2016a, 2016b, Rytter 2016) Those studies found no changes in soil or ganic carbon (SOC) or total nitrogen (Tot $\mathrm{N}$ ) in the upper $30 \mathrm{~cm}$ soil 5-15 years after planting, but observed an increase of $K$ and $\mathrm{Mg}$ in the top $10 \mathrm{~cm}$ soil and a decrease be low, indicating a redistribution of those base cations from deeper soil layers to the upper soil (Rytter 2016), and decreases in $\mathrm{CN}$ ratios and $\mathrm{pH}$ over time (Lutter et al. 2016b, Rytter 2016).

Effects of forest management on SOC and Tot $\mathrm{N}$ are important to understand from the aspects of soil fertility and C storing capability. Harvesting removes biomass, disturbs the soil and changes the microclimate which may lead to increased $C$ losses in the soil (Jandl et al. 2007). However, a meta-analysis found that forest harvesting on average had little or no effect on soil $\mathrm{C}$ or $\mathrm{N}$, except for conifers where saw log harvesting caused increases and whole tree harvesting decreases (Johnson $\&$ Curtis 2001). Thinning measures result in similar primary effects as harvesting, i.e., soil disturbance and altered microclimate, but less experimental knowledge on the effects of thinning on soil properties is available (Jandl et al. 2007). Most of the literature on harvesting and thinning effects on soil characteristics to date refers to conifers. A study of spruce and pine on podsol found that the effects of repeated thinning on soil chemistry $(\mathrm{pH}, \mathrm{C}, \mathrm{N}, \mathrm{P}$ and base cations) were variable but generally small (Rosenberg \& Jacobson 2004).

Studies on growth performance and effects of management on the next generation of hybrid aspen plantations, i.e., shoots generated from root suckers after clear cutting of the original stand, have recently been initiated in Sweden (McCarthy \& Rytter 2015). An evaluation of productivity and sustainability of second-generation hybrid aspen subjected to different management regimes with respect to length of rotation period and extent of thinning measures has been made eight years after initiation (Rytter \& Rytter 2017). The management regimes included 4-, 8- and 16year rotations with thinning measures in the two longer rotations. The 16-year rotation had not yet reached full time and was evaluated midterm. All regimes included removal of biomass after harvest or thinning measures, except for a latter thinning in the 16-year rotation. A simultaneous study of the effects of those management regimes on soil characteristics was performed and is reported here. We wanted to test the hypotheses that: (1) mineral soil characteristics, i.e., concentrations and pools of SOC, Tot $\mathrm{N}$, base cations and $\mathrm{pH}$, would be significantly influenced by management regime; and (2) changes in soil characteristics could be reflected in the amount and timing of removed biomass, including nutrients, at harvest and thinning operations.

\section{Materials and methods}

\section{Site description}

The study was performed in root sucker plots of hybrid aspen (Populus tremula L. $\times$ $P$. tremuloides Michx.). The site is situated in southern Sweden at latitude $55^{\circ} 33^{\prime} \mathrm{N}$, longitude $13^{\circ} 43^{\prime} \mathrm{E}$ and elevation $40-45 \mathrm{~m}$ above sea level. The vegetation period, de- fined as degree days above $5{ }^{\circ} \mathrm{C}$, averaged 209 days during 2007-2016 (SMHI 2018a). Mean temperature and precipitation were $-1.1^{\circ} \mathrm{C}$ and $58.5 \mathrm{~mm}$ in January, respectively, and $15.9^{\circ} \mathrm{C}$ and $67.4 \mathrm{~mm}$ in July during the current climate normal period (1961-1990 climate norms - SMHI 2018b). The soil is a clayey moraine, i.e., an unsorted sediment of glacial origin which is typical for this part of Sweden (Tab. 1). The site is a former arable land distinguished by a humus rich topsoil and a compacted plough pan below at around $30 \mathrm{~cm}$ depth. The topsoil layer is characterized as a special form of mull which contains more mineral than organic material (White 2006). Larger stones have been removed during an extended period of arable use and repeated ploughing and harrowing have created a homogeneous distribution of the remaining stones in the topsoil.

\section{Experimental design}

A clonal mix of hybrid aspen was planted on 3.5 ha in spring 1998 . One-year-old hybrid aspen plants were planted with a spacing of $3 \times 3 \mathrm{~m}$, giving a density of 1100 plants ha ${ }^{-1}$. In total, 14 plots $(30 \times 30 \mathrm{~m})$ were planted with eight selected clones delivered from Ekebo Research Station, Forestry Research Institute of Sweden. The space between the plots were $6 \mathrm{~m}$ at the minimum and planted with other commercial clones. The plantation was harvested in the winter 2008/2009 when total tree age was 12 years. Four blocks, each including three plots with different management regimes, were identified based on recorded standing biomass after 2 years. The randomized placing of management regimes within blocks was also applied at the end of the second season after clear-cutting. The two plots not used in the study were kept as reserves. Three different management regimes were tested: (i) $4 \mathrm{YR}$, rotation periods of four years with removal of biomass at each harvest; (ii) $8 \mathrm{YR}$, rotation periods of eight years including cleaning in corridors, where biomass was removed, after four years and total harvest of biomass after eight years; (iii) $8+Y R$, rotation periods of 16 years, where the first eight years were included in the present study, including corridor cleaning with removal of biomass after two years and thinning of the remaining stems to $1100-1200$ stems $^{-1}$ af $^{-1}$ af ter four years. No biomass was taken out at the latter thinning.

The cleaned corridors were $3-3.5 \mathrm{~m}$ wide and the strips with shoots were 1-2 m wide. For more details on the different management regimes see Rytter \& Rytter (2017).

\section{Harvested biomass and nutrient} removal

Measurement of standing biomass started in autumn 2009 and occurred repeatedly with 1-2 years interval during the forthcoming 8 years. A detailed description of the measurement procedures is given in Rytter \& Rytter (2017). All shoots/trees in 
sample plots (3-6 plots of $10-15 \mathrm{~m}^{2}$ ) and net plots, i.e., $30 \times 30 \mathrm{~m}$ (treatment $8+\mathrm{YR}$ ) were measured for breast height diameter over bark (dbh), while height was measured on every fifth shoot/tree. Height of the remaining shoots/trees was calculated from functions produced from the heightmeasured individuals using the formula (eqn. 1):

$$
H=a D^{b}
$$

where $H$ is stem height, $D$ diameter at breast height $(1.3 \mathrm{~m})$, and $a$ and $b$ are constants.

Samples for estimation of stem dry weight were collected simultaneously as diameter measurement. A total of 20-30 shoots/trees of various sizes were collected from each treatment on each sampling occasion. The samples were treated as whole shoots or as a series of discs for determination of wood density and weight. Basic density of wood was recorded on the discs to allow calculation of stem weight for the larger trees (Rytter \& Rytter 2017). The water displacement method was used (Olesen 1971). Branches were treated separately. After biomass determination of the shoots/trees, relations between diameter and height to dry biomass were constructed using the formulas (eqn. 2, eqn. 3):

$$
\begin{aligned}
& W_{s}=c\left(D^{2} H\right)^{d} \\
& W_{t}=e\left(D^{2} H\right)^{f}
\end{aligned}
$$

where $W_{s}$ and $W_{t}$ are stem and branch dry weight, respectively, $D$ is the stem diameter, $H$ is the stem height and $c, d, e$ and $f$ are constants. The result of the biomass measurements (Tab. 2) was also previously presented in Rytter \& Rytter (2017).

To produce a representative sample for nutrient analyses of the shoots/trees, sawdust was collected from sawing down to the pith at each $2 \mathrm{~m}$ section of the stem, i.e., the sampled discs for biomass determination were used in this purpose for the bigger trees. An equal number of saw tracks was used at each stem section for the individual tree. In this way a volumebased representative sample for the shoot/ tree was achieved.

Carbon (C) as well as macronutrients were analysed on the collected sawdust from respective sample shoot/tree. Total $C$ and nitrogen $(\mathrm{N})$ were analysed by dry combustion of the sample with an elemental analyser (LECO TruMac ${ }^{\oplus}$, Leco Corp., St Joseph, MI, USA). Samples for analysis of phosphorus $(\mathrm{P})$, sulphur $(\mathrm{S})$, potassium $(\mathrm{K})$, magnesium (Mg) and calcium (Ca) were digested with $65 \% \mathrm{HNO}_{3}$ and analysed with ICP-OES (Inductively Coupled Plasma with Optical Emission Spectrometry, Avio $200^{\circledR}$, Perkin Elmer, USA).

\section{Soil sampling and analyses}

An initial sampling of the mineral soil down to the plough pan, i.e., at approximately $30 \mathrm{~cm}$ depth, was conducted in connection with harvest of the original stand and reflected the soil conditions before clear-cutting and application of the different management regimes (4YR, 8YR, $8+Y R)$. A second soil sampling was performed in the winter after eight years with different management. A core sampler with the length $30 \mathrm{~cm}$, outer diameter 25 $\mathrm{mm}$ and inner diameter $20 \mathrm{~mm}$ was used. Twenty core samples were collected to 30 $\mathrm{cm}$ depth on each plot, i.e., on twelve plots on both sampling occasions. Each core sample was divided into two fractions, 0-15 $\mathrm{cm}$ and $15-30 \mathrm{~cm}$, and pooled into one sample per depth fraction and plot giving a total of 48 soil samples ( 2 occasions $\times 12$ plots $\times 2$ depths) which were further processed and analysed for nutrient content and $\mathrm{pH}$. In addition, three soil cores from each plot were taken at the latter sampling occasion for determination of bulk density of the fine earth fraction (particle size $<2 \mathrm{~mm}$ ), gravel volume and coarse organic material in the soil.

Chemical analyses were performed on the homogenized and dried fine earth fraction. Total C (Tot C) and total N (Tot N) were analysed by dry combustion of the sample with an elemental analyser (LECO TruMac). Plant available $P$ and base cations ( $\mathrm{K}, \mathrm{Mg}, \mathrm{Ca}$ ) were extracted with Mehlich III solution (AgroEcoLab@UMD 2018) and analysed with plasma analysis (ICP-OES Avio 200). Soil samples for analyses of nitrogen in nitrate $\left(\mathrm{NO}_{3}-\mathrm{N}\right)$ and in ammonium $\left(\mathrm{NH}_{4}^{-}\right.$ $\mathrm{N}$ ) were extracted in $2 \mathrm{M} \mathrm{KCl}$ and analysed by spectrophotometry (AutoAnalyzer, $\mathrm{AA}^{\oplus}{ }^{\oplus}$, Seal Analytical $\mathrm{GmbH}$, Norderstedt, Germany). The $\mathrm{pH}$ was measured in airdried soil suspended in deionised water according to the standard SS-ISO 10390.

The content of inorganic C (carbonates) in Swedish arable soils were considered negligible at $\mathrm{pH}<6$ in a comprehensive study (Eriksson et al. 2010). The soil pH in the present study ranged between 5.1-5.8 and we assumed that the Tot $C$ values were approximate estimates of soil organic car-

Tab. 2 - Harvested and standing biomass during the 8-year study period for the three management regimes. Mean values $(n=4)$ of respective management and measurement occasion are shown. The thinning biomass in the $8+Y R$ regime year 4 was not removed from the plots. Data taken from Rytter \& Rytter (2017).

\begin{tabular}{llccc}
\hline $\begin{array}{l}\text { Management } \\
\text { regime }\end{array}$ & Type & Year & $\begin{array}{c}\text { Age } \\
\text { (yrs) }\end{array}$ & $\begin{array}{c}\text { Biomass } \\
\left(\text { Mg DM ha }^{-1}\right)\end{array}$ \\
\hline 4YR & Harvest & 2012 & 4 & 45.82 \\
& Harvest & 2016 & 4 & 52.48 \\
& Total outtake & - & - & 98.31 \\
\hline 8YR & Harvest & 2012 & 4 & 25.53 \\
& Harvest & 2016 & 8 & 67.05 \\
& Total outtake & - & - & 92.59 \\
\hline \multirow{3}{*}{$8+$ YR } & Harvest & 2010 & 2 & 17.78 \\
& Thinning & 2012 & 4 & 15.79 \\
& Remaining & 2016 & 8 & 53.62 \\
& Outtake, thinning and remaining & - & - & 87.17 \\
\hline
\end{tabular}

bon (SOC).

Bulk density of the fine earth to $30 \mathrm{~cm}$ ume of the core sampler $\left(94.25 \mathrm{~cm}^{2}\right)$. The soil from the sampler was sieved $(2 \mathrm{~mm}$ hole diameter) to separate fine earth from gravel $(2-20 \mathrm{~mm})$ and coarse organic material $(2-20 \mathrm{~mm})$. All fractions were dried at $70^{\circ} \mathrm{C}$ to constant weight and weighed. The bulk density of the fine earth was calculated by using the formula (eqn. 4):

$$
\begin{aligned}
\rho=\frac{M}{V} & =\frac{M_{c s}-M_{2-20 \mathrm{~mm}}}{V_{c s}-V_{2-20 \mathrm{~mm}}} \\
& =\frac{M_{c s}-M_{2-20 \mathrm{~mm}}}{V_{c s}-\left(M_{2-20 \mathrm{~mm}} / \rho_{g r}\right)}
\end{aligned}
$$

where $\rho$ is the bulk density of fine earth $<2$ $\mathrm{mm}\left(\mathrm{g} \mathrm{cm}^{-3}\right), M$ is the mass of fine earth taken with core sampler (g), $\mathrm{V}$ is the volume of the undisturbed fine earth $\left(\mathrm{cm}^{3}\right)$, $M_{\mathrm{cs}}$ is the mass of soil sample, including gravel, taken with core sampler (g), $V_{c s}$ is the volume of the core sampler $\left(\mathrm{cm}^{3}\right)$, $M_{2-20 \mathrm{~mm}}$ is the mass of gravel (2-20 mm, g), $\mathrm{V}_{2-20 \mathrm{~mm}}$ is the volume of gravel $\left(\mathrm{cm}^{3}\right), \rho_{\mathrm{gr}}$ is the mean density of granite $\left(2.650 \mathrm{~g} \mathrm{~cm}^{-3}\right)$. Eventual soil shrinkage was not compensated for.

Soil nutrient content ( $\left.N t_{\text {content }}\right)$ was calculated by multiplying nutrient concentration by the volume of fine earth according to McNabb et al. (1986 - eqn. 5):

$$
N t_{\text {content }}=\rho \cdot\left(1-\sigma_{2-20 \mathrm{~mm}}\right) \cdot d \cdot N t_{\text {concentration }}
$$

where $\rho$ is the bulk density of fine earth $<2$ $\mathrm{mm}\left(\mathrm{g} \mathrm{cm}^{-3}\right), \sigma_{2-20 \mathrm{~mm}}$ is the relative volume of gravel, $d$ is the sampling depth $(\mathrm{cm}), \mathrm{Nt}_{\text {con- }}$ centration is the concentration of nutrient ( $g$ $\mathrm{g}^{-1}$ ). The relative stone volume (particle size $\geq 20 \mathrm{~mm}$ ) to $30 \mathrm{~cm}$ depth, was not investigated in the present study. However, an earlier investigation of stoniness (20-200 $\mathrm{mm}$ ) showed that the relative stone volume was about $4 \%$ in arable soils of this region (Rytter 2012b). Accordingly, it was assumed that the influence of stoniness would only give a minor effect on estimates of nutrient stocks in the present soil depth was estimated by using the vol- 
Tab. 3 - Data on the biomass removed at thinning and harvest, including removed amounts of macro nutrients $(n=4)$. $D_{a}$ is the arithmetic breast height diameter $(1.3 \mathrm{~m})$ of harvested shoots/trees.

\begin{tabular}{|c|c|c|c|c|c|c|c|c|c|c|c|c|}
\hline \multirow{2}{*}{$\begin{array}{l}\text { Management } \\
\text { regime }\end{array}$} & \multirow{2}{*}{ Type } & \multirow{2}{*}{$\begin{array}{l}D_{a} \\
(\mathrm{~cm})\end{array}$} & \multirow{2}{*}{ Year } & \multirow{2}{*}{$\begin{array}{l}\text { Age } \\
\text { (yrs) }\end{array}$} & \multicolumn{8}{|c|}{ Removed biomass, $\mathrm{C}\left(\mathrm{Mg} \mathrm{ha}^{-1}\right)$ and nutrients (kg ha-1) } \\
\hline & & & & & Biomass & $C$ & $\mathrm{~N}$ & $\mathbf{P}$ & $\mathrm{K}$ & $\mathrm{Ca}$ & Mg & $S$ \\
\hline \multirow[t]{3}{*}{$4 \mathrm{YR}$} & Harvest & 2.90 & 2012 & 4 & 45.82 & 20.91 & 159 & 24.7 & 109 & 190 & 21.0 & 11.4 \\
\hline & Harvest & 3.26 & 2016 & 4 & 52.48 & 23.95 & 163 & 31.9 & 122 & 292 & 22.7 & 15.1 \\
\hline & Total removal & - & - & - & 98.31 & 44.86 & 322 & 56.6 & 232 & 482 & 43.7 & 26.5 \\
\hline \multirow[t]{3}{*}{$8 Y R$} & Thinning & 2.61 & 2012 & 4 & 25.53 & 11.65 & 88.3 & 15.1 & 66.9 & 118 & 12.8 & 6.9 \\
\hline & Harvest & 5.25 & 2016 & 8 & 67.05 & 31.11 & 135 & 26.1 & 111 & 206 & 21.6 & 11.0 \\
\hline & Total removal & - & - & - & 92.59 & 42.76 & 223 & 41.2 & 178 & 324 & 34.4 & 17.9 \\
\hline \multirow[t]{3}{*}{$8+Y R$} & Thinning & 1.67 & 2010 & 2 & 17.78 & 8.11 & 144 & 15.6 & 65.8 & 104 & 12.6 & 8.7 \\
\hline & Thinning & - & 2012 & 4 & 0 & 0 & 0 & 0 & 0 & 0 & 0 & 0 \\
\hline & Total removal & - & - & - & 17.78 & 8.11 & 144 & 15.6 & 65.8 & 104 & 12.6 & 8.7 \\
\hline
\end{tabular}

study and that the comparison of management regimes would not be hampered since the soil was of the same origin for all treatment plots.

\section{Statistics}

Statistical analyses were performed with $R$ version 3.4.2 ( $R$ Core Team 2017). Analyses of variance (ANOVA) were conducted by using the R built-in function "aov" for balanced data. A two-factor factorial model was used to test for equality in means of bulk density, gravel and organic material in the soil between different management regimes and is described by (eqn. 6):

$$
y_{i j k}=\mu+s_{i}+t_{j}+\varepsilon_{i j k}
$$

(6) where $y_{\text {ghijk }}$ is the ghijk ${ }^{\text {th }}$ observation, $\mu$ is the overall mean, $q_{\mathrm{g}}$ is the fixed effect of the $g^{\text {th }}$ depth, $r_{h}$ is the fixed effect of the $h^{\text {th }}$ year, $s_{\mathrm{i}}$ is the fixed effect of the $i^{\text {th }}$ treatment, $t_{j}$ is the random effect of the $j^{\text {th }}$

overall $y_{i j}$ is the ijk observation, $\mu$ is the treatment, $t_{\mathrm{j}}$ is the random effect of the $j^{\text {th }}$

block, and $\varepsilon_{\mathrm{ijk}}$ is the random error term for observation ijk. The fixed effect of management regime was tested with meansquare of block and treatment as the error term. The same design was used to test for equality in means of nutrient pools $(\mathrm{Mg}$ $\left.\mathrm{ha}^{-1}\right)$ and nutrient concentrations ( $\left.\mathrm{mg} \mathrm{kg}^{-1}\right)$ between management regimes.

A four-factor factorial design was performed to test for equality in means of $\mathrm{pH}$ and nutrient concentrations ( $\mathrm{mg} \mathrm{kg}^{-1}$ ) between years, depth and the different management regimes (eqn. 7):

$$
y_{g h j k}=\mu+q_{g}+r_{h}+s_{i}+t_{j}+\varepsilon_{g h i j k}
$$

\section{Nutrient removal with harvests}

The biomass was removed from the site at all management operations, except at the thinning year 4 in the $8+Y R$ management regime. The regime with highest biomass removal also showed the highest removal of carbon and nutrients (Tab. 3). For example, $322 \mathrm{~kg} \mathrm{~N}^{-1}$ was removed at the $4 \mathrm{YR}$ regime, $223 \mathrm{~kg} \mathrm{~N} \mathrm{ha}^{-1}$ in the $8 \mathrm{YR}$, and only $144 \mathrm{~kg} \mathrm{~N} \mathrm{ha}^{-1}$ in the $8+\mathrm{YR}$ after 8 years. The low outtake of biomass and nutrients in the $8+Y R$ was a result of leaving the material on the site at the second thinning and that no final harvest is to be done before the age of 16 years.

Although the 8+YR showed the smallest total outtake of nutrients, the nutrient amount per harvested unit of biomass was highest, $8.1 \mathrm{~kg} \mathrm{~N} \mathrm{Mg}^{-1}$ of biomass. A clear negative relation was seen between average tree diameter, and thereby also shoot age, and nutrient concentration (Fig. 1).

Soil nutrient concentrations and $\mathrm{pH}$

A statistically significant but small difference in SOC concentration was detected for different managed root sucker plots with hybrid aspen (Fig. 2a, Tab. 4). The 8YR management regime showed lower SOC concentrations when both depth levels were included in the analyses, but not for each depth alone. The upper $0-15 \mathrm{~cm}$ soil contained higher mean $\mathrm{SOC}$ concentrations compared to the $15-30 \mathrm{~cm}$ level irrespective of management regime. Mean SOC concentrations were $21.2-24.5$ and $10.5-15.3 \mathrm{~g} \mathrm{~kg}^{-1}$ in the upper and lower soil level, respectively.
Fig. 1 - The relation between average tree diameter at the harvest or thinning occasion and nutrient concentration in harvested biomass, exemplified by $\mathrm{N}, \mathrm{P}$ and $\mathrm{K}$. Every data point is a mean from four sample trees of similar size for which the elements were analysed. 
Fig. 2 - (a) Soil organic carbon (SOC) concentrations ( $\left.\mathrm{mg} \mathrm{kg} \mathrm{kg}^{-1}\right),(\mathrm{b})$ total nitrogen (Tot $\mathrm{N}$ ) concentrations ( $\mathrm{mg}$ $\left.\mathrm{kg}^{-1}\right)$, and (c) $\mathrm{CN}$-ratios in 0-15 and $15-30 \mathrm{~cm}$ mineral soil. Means and standard error bars are shown $(n=4$, each $n$ consisted of 20 subsamples).

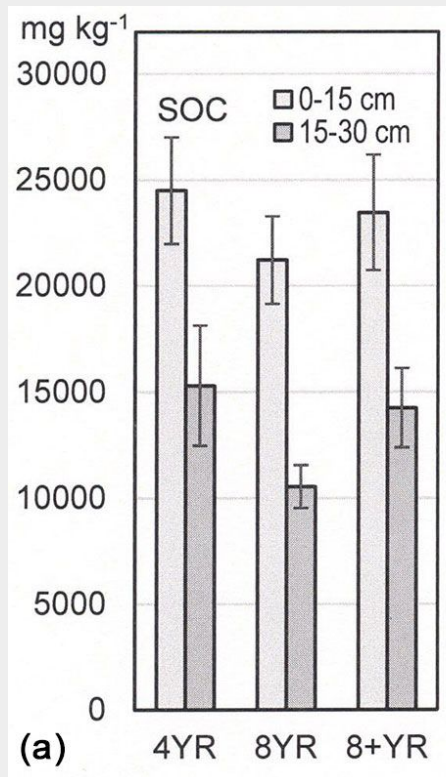

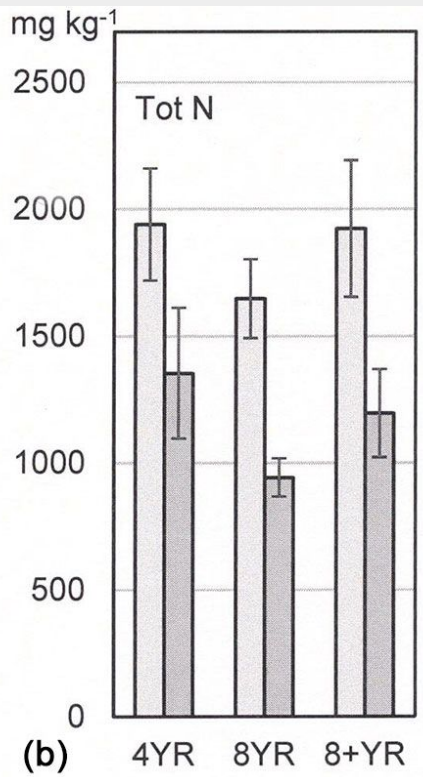

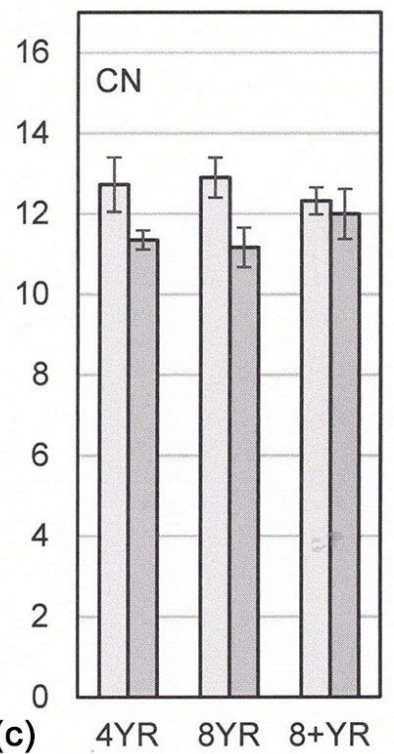

Concentrations of Tot $\mathrm{N}$ in the mineral soil did not differ between management regimes (Fig. 2b, Tab. 4). Differences between depth levels were observed and higher concentrations were found in the top $15 \mathrm{~cm}$ soil. Mean Tot $\mathrm{N}$ concentrations were $1.6-1.9 \mathrm{~g} \mathrm{~kg}^{-1}$ in the top $15 \mathrm{~cm}$ soil and $0.9-1.4 \mathrm{~g} \mathrm{~kg}^{-1}$ in the lower soil depth.

The soil $\mathrm{CN}$ ratio was not affected by management regime (Fig. 2c, Tab. 4). Mean $\mathrm{CN}$ ratios were higher in the $0-15 \mathrm{~cm}$ soil level and ranged between 12.3-12.9, compared to $11.2-12.0$ in the $15-30 \mathrm{~cm}$ level.

Soil $\mathrm{pH}$ did not change significantly over time and did not differ between management regimes or depth levels. Mean $\mathrm{pH}$ values were 5.4-5.6 at the time of clear cutting and 5.5-5.8 after 8 years of management (Fig. 3a, Tab. 4).

The vertical distributions of ammonium and nitrate concentrations in the mineral soil changed differently during the study period (Fig. 3b). An increase in $\mathrm{NH}_{4}-\mathrm{N}$ concentrations could be seen in the top $15 \mathrm{~cm}$ soil in all management regimes, but no differences between the regimes were observed (Tab. 4). Mean concentrations ranged between 9.9 and $13.0 \mathrm{mg} \mathrm{kg}^{-1}$ after eight years. The $\mathrm{NH}_{4}-\mathrm{N}$ concentrations in the deeper $15-30 \mathrm{~cm}$ soil were lower, 2.9$4.2 \mathrm{mg} \mathrm{kg}^{-1}$, and were unaffected by management regime and time. Nitrate concentrations decreased in both soil depths, but statistically significant only in the lower 15 $30 \mathrm{~cm}$ soil (Fig. 3b, Tab. 4). A small but statistically significant difference between the 4 YR and 8 YR regime was found.

Soil phosphorus concentrations were relatively stable during the study period and no management effects were detected (Fig. 4, Tab. 4). Somewhat higher P concentrations were found in the top $0-15 \mathrm{~cm}$ soil compared to the lower soil layer. The concentrations during the study period ranged between $150-180$ and $120-150 \mathrm{mg} \mathrm{kg}^{-1}$ in the 0-15 and 15-30 cm soil depth, respectively.

Base cation ( $\mathrm{K}, \mathrm{Ca}, \mathrm{Mg}$ ) concentrations in
Tab. 4 - Results from analyses of variance (ANOVA) of soil pH and nutrient concentrations including two depth levels, three management regimes and two sampling occasions, i.e., at the application of management regimes and eight years later. ANOVA was also performed within each depth level. A difference was accepted as significant if $\mathrm{p} \leq 0.05$.

\begin{tabular}{|c|c|c|c|c|c|}
\hline \multirow{2}{*}{ Variable } & \multicolumn{2}{|c|}{ Depth } & \multirow{2}{*}{$\begin{array}{c}\text { Management } \\
\text { p-value }\end{array}$} & \multirow{2}{*}{$\begin{array}{c}\text { Year } \\
\text { p-value }\end{array}$} & \multirow{2}{*}{ Change } \\
\hline & $\mathrm{cm}$ & p-value & & & \\
\hline \multirow[t]{3}{*}{ Tot C } & Both & $<0.0001$ & 0.0476 & - & - \\
\hline & $0-15$ & - & 0.474 & - & - \\
\hline & $15-30$ & - & 0.180 & - & - \\
\hline \multirow[t]{3}{*}{ Tot $\mathrm{N}$} & Both & 0.0001 & 0.181 & - & - \\
\hline & $0-15$ & - & 0.574 & - & - \\
\hline & $15-30$ & - & 0.489 & - & - \\
\hline \multirow[t]{3}{*}{$\mathrm{CN}$} & Both & 0.0085 & 0.108 & - & - \\
\hline & $0-15$ & - & 0.654 & - & - \\
\hline & $15-30$ & - & 0.077 & - & - \\
\hline \multirow[t]{3}{*}{$\mathrm{pH}$} & Both & 0.680 & 0.123 & 0.698 & - \\
\hline & $0-15$ & - & 0.295 & 0.289 & - \\
\hline & $15-30$ & - & 0.452 & 0.583 & - \\
\hline \multirow[t]{3}{*}{$\mathrm{NH}_{4}-\mathrm{N}$} & Both & $<0.0001$ & 0.670 & $<0.0001$ & - \\
\hline & $0-15$ & - & 0.446 & $<0.0001$ & increase \\
\hline & $15-30$ & - & 0.144 & 0.326 & - \\
\hline \multirow[t]{3}{*}{$\mathrm{NO}_{3}-\mathrm{N}$} & Both & 0.419 & 0.0288 & 0.0010 & - \\
\hline & $0-15$ & - & 0.133 & 0.0842 & - \\
\hline & $15-30$ & - & 0.309 & 0.0116 & decrease \\
\hline \multirow[t]{3}{*}{$P$} & Both & 0.0081 & 0.0598 & 0.656 & - \\
\hline & $0-15$ & - & 0.137 & 0.702 & - \\
\hline & $15-30$ & - & 0.560 & 0.849 & - \\
\hline \multirow[t]{3}{*}{ K } & Both & $<0.0001$ & 0.645 & $<0.0001$ & - \\
\hline & $0-15$ & - & 0.496 & $<0.0001$ & increase \\
\hline & $15-30$ & - & 0.238 & 0.200 & - \\
\hline \multirow[t]{3}{*}{$\mathrm{Ca}$} & Both & 0.775 & 0.374 & 0.426 & - \\
\hline & $0-15$ & - & 0.743 & 0.295 & - \\
\hline & $15-30$ & - & 0.550 & 0.995 & - \\
\hline \multirow[t]{3}{*}{$\mathrm{Mg}$} & Both & 0.0189 & 0.552 & $<0.0001$ & - \\
\hline & $0-15$ & - & 0.859 & 0.0005 & increase \\
\hline & $15-30$ & - & 0.655 & 0.0013 & increase \\
\hline
\end{tabular}




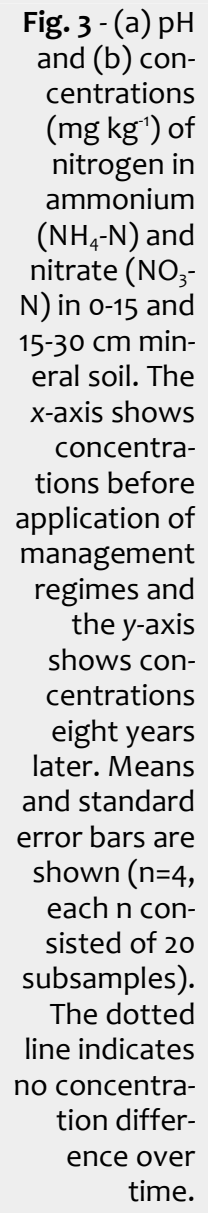

Fig. 3 - (a) $\mathrm{pH}$ and (b) concentrations $\left(\mathrm{mg} \mathrm{kg}^{-1}\right)$ of nitrogen in ammonium $\left(\mathrm{NH}_{4}-\mathrm{N}\right)$ and nitrate $\left(\mathrm{NO}_{3}-\right.$ $\mathrm{N}$ ) in 0-15 and $15-30 \mathrm{~cm}$ mineral soil. The $x$-axis shows concentrations before application of management regimes and the $y$-axis shows concentrations eight years later. Means and standard error bars are shown $(n=4$, each $n$ consisted of 20 subsamples).

The dotted line indicates no concentration difference over time.
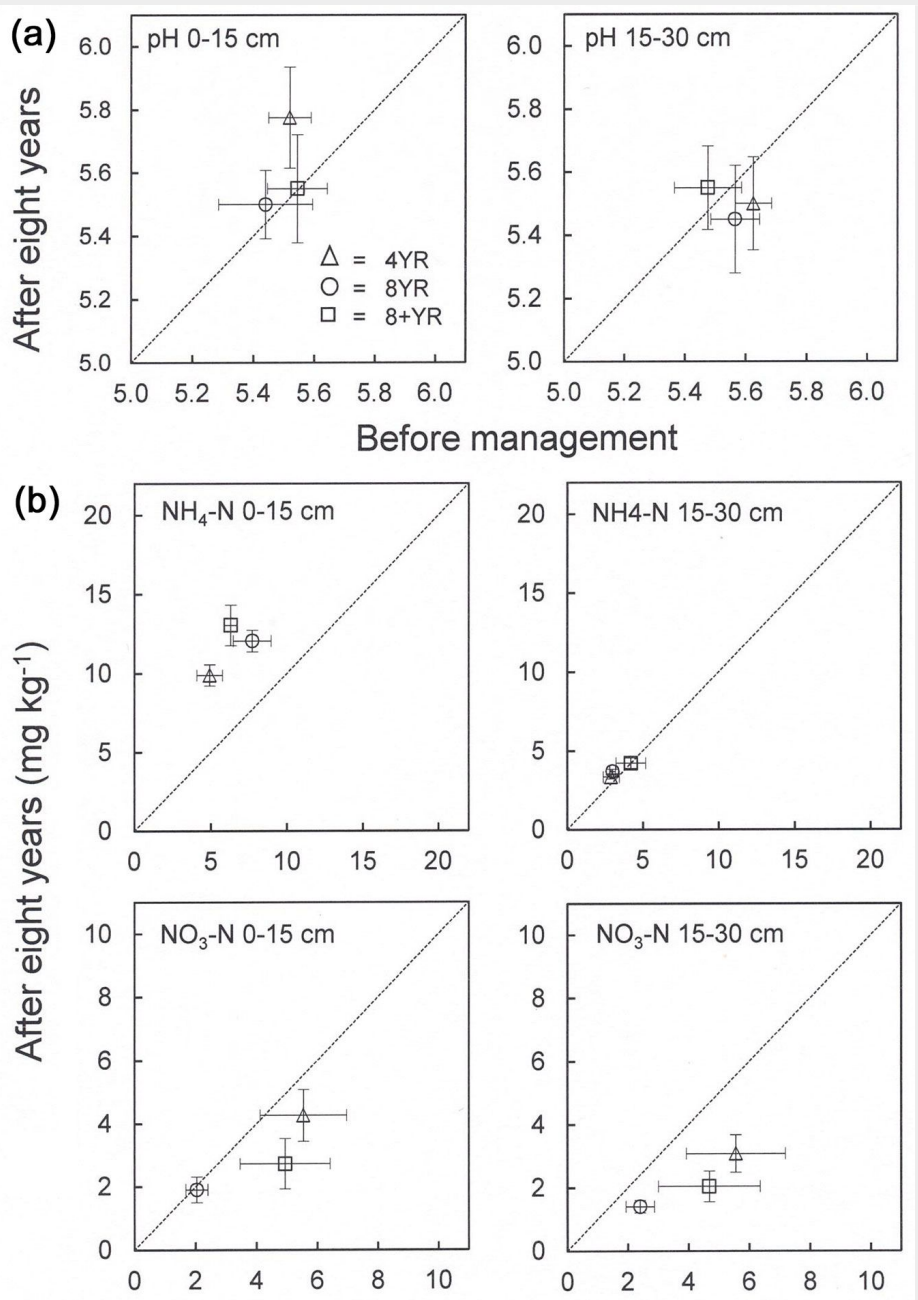

Before management $\left(\mathrm{mg} \mathrm{kg}^{-1}\right)$ the mineral soil were not affected by management regime (Fig. 4, Tab. 4). Concentrations of $\mathrm{K}$ and $\mathrm{Mg}$ increased during the study period while Ca concentrations were stable in all regimes. Potassium concentrations increased in the top $0-15 \mathrm{~cm}$ soil and $\mathrm{Mg}$ concentration increased in both soil depths. Concentrations of $\mathrm{K}$ and $\mathrm{Mg}$ varied with soil depth, while concentrations of $\mathrm{Ca}$ were similar. Mean $\mathrm{K}$ concentrations were 190-210 and 55-67 mg kg-1 in the 0-15 and 15$30 \mathrm{~cm}$ depth, respectively, and corresponding mean Mg concentrations were 160-190 and $120-160 \mathrm{mg} \mathrm{kg}^{-1}$ in all management regimes. Mean $\mathrm{Ca}$ concentrations ranged between 900-1800 $\mathrm{mg} \mathrm{kg}^{-1}$, including all management regimes, depths and years.

\section{Bulk density and soil nutrient pools}

Bulk density of the fine earth and relative gravel volume of the soil to $30 \mathrm{~cm}$ depth were estimated at the end of the current study period. No significant differences in bulk density caused by different management regimes could be detected (Tab. 5). The relative gravel volume was low in all regimes as well as the content of coarser organic material, i.e., small roots and not fully decomposed litter.

The calculated soil nutrient pools did not differ between the various management regimes for root suckers of hybrid aspen (Tab. 6). The slightly lower SOC concentration observed in the 8YR regime (Fig. $2 \mathrm{a}$ ) was reflected in the SOC pool but it was not statistically significant. The $\mathrm{CN}$ ratios calculated from $\mathrm{SOC}$ and Tot $\mathrm{N}$ pools $(\mathrm{Mg}$ $\mathrm{ha}^{-1}$ ) included the soil depth $0-30 \mathrm{~cm}$ and showed similar figures, i.e., 12.2-12.3, in all
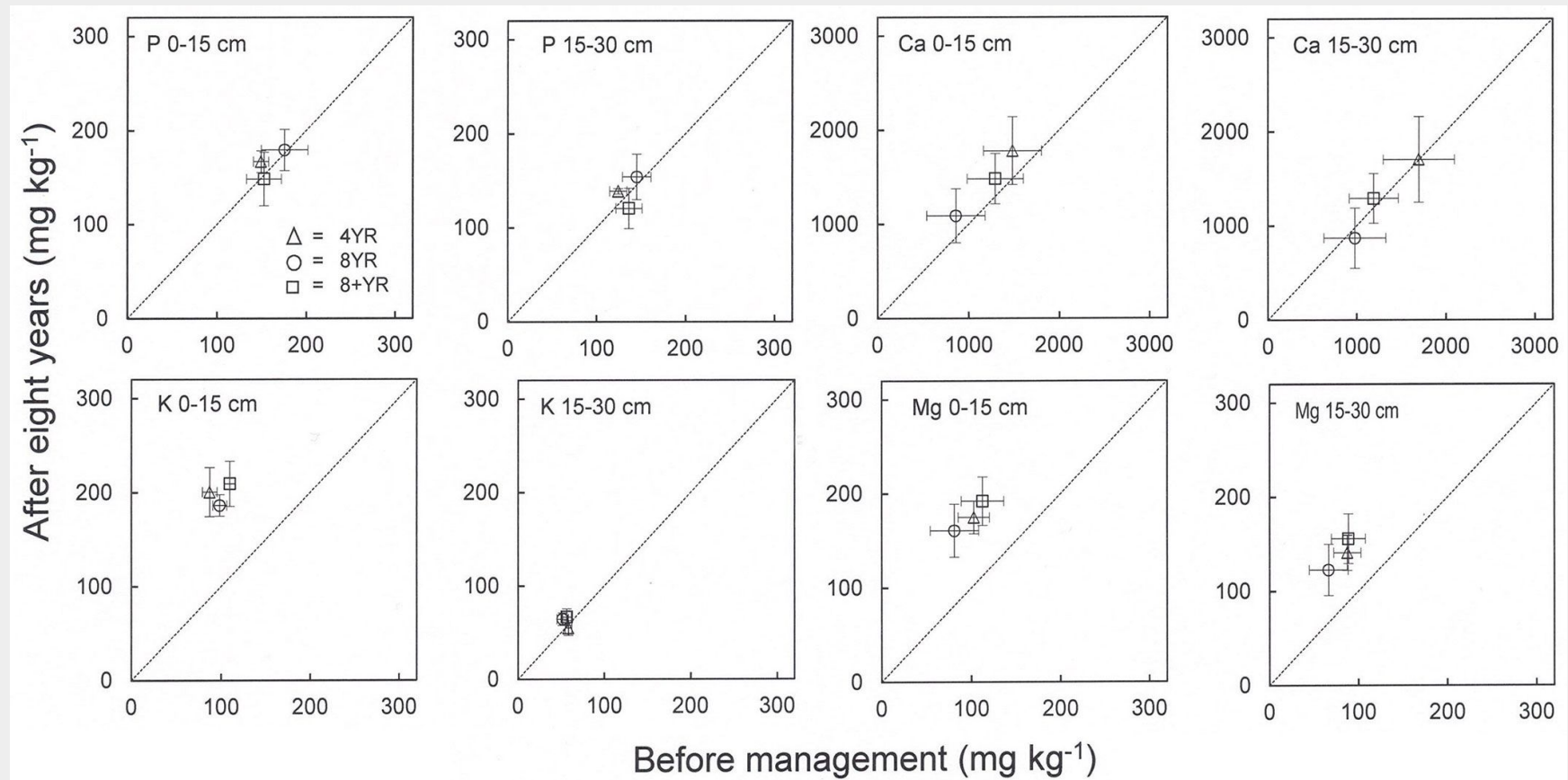

Before management $\left(\mathrm{mg} \mathrm{kg}^{-1}\right)$

Fig. 4 - Concentrations $\left(\mathrm{mg} \mathrm{kg}^{-1}\right)$ of plant available phosphorus ( $\left.\mathrm{P}\right)$ and base cations (K, Ca, Mg) in 0-15 and 15-30 cm mineral soil. The $x$-axis shows concentrations before application of management regimes and the $y$-axis shows concentrations eight years later. Means and standard error bars are shown ( $n=4$, each $n$ consisting of 20 subsamples). The dotted line indicates no concentration difference over time. 
regimes. The pools of $\mathrm{P}, \mathrm{K}$ and $\mathrm{Mg}$ were of the same magnitude, $0.4-0.6 \mathrm{Mg} \mathrm{ha}^{-1}$, in all management regimes, while the Ca pools were about ten times larger.

\section{Discussion}

We found few significant effects on mineral soil properties related to the different management regimes after eight years in root sucker stands with hybrid aspen (hypothesis 1). Different harvest intervals and different degrees of thinning with removal of biomass (Tab. 3) caused no differences in SOC pool sizes (Tab. 6) and SOC concentrations showed only a minor statistical significant divergence for the 8YR from the other regimes (Fig. 2a, Tab. 4). This minor difference might be due to the removal of many shoots and a large part of the biomass in corridor cleaning after 4 years in the $8 \mathrm{YR}$ treatment, thereby leaving gaps in the corridors for some time, which probably resulted in less production of leaf and root litter. However, the SOC pool was not affected so this tendency needs to be followed to get accurate information on SOC development.

Few studies have been conducted on the impact of harvesting or thinning intervals on soil properties in poplar plantations, and none in hybrid aspen stands so far. It has been suggested that short rotation forestry in general would have a positive impact on C sequestration (Hedenus \& Azar 2009) and that hybrid poplar plantations with rotations longer than four years could act as C sinks (Arevalo et al. 2011). Other results from stem harvesting or thinning impact on mineral soil $C$ stocks in temperate forests are variable and more studies are requested on the subject (Nave et al. 2010). The meta-analysis by Nave et al. (2010) found no significant overall change in C storage in mineral soils caused by stem harvesting. Likewise, thinning studies with various intensities and time intervals revealed either no effects on or minor decreases of $C$ pools in the mineral soil (Rosenberg \& Jacobson 2004, Nilsen \& Strand 2008, Jurgensen et al. 2012), but the literature on harvesting and thinning effects on soil $C$ in temperate forests refers to a high degree to conifers. Comparative studies on this subject revealed that hardwoods in general lose more forest floor $\mathrm{C}$ than coniferous/mixed stands, while the situation in the mineral soil seems to be more dependent on soil type (Nave et al. 2010, Jurgensen et al. 2012). The different management regimes for root sucker generated by hybrid aspen tested in the present study did not affect the SOC pool sizes in the mineral soil after eight years. However, it is important to follow effects of management on soil properties over several rotations.

Removed biomass quantities were largest in the management regimes with the shortest rotations, $4 \mathrm{YR}$ and $8 \mathrm{YR}$, and it reflected the extent of $\mathrm{C}$ and nutrient removal (Tab. 3). The dimensions of har-

Tab. 5 - Bulk density of fine earth (particle size $<2 \mathrm{~mm}$ ), relative volume of gravel (2-20 $\mathrm{mm}$ ) and content per soil volume of coarse organic material $(2-20 \mathrm{~mm})$ to $30 \mathrm{~cm}$ soil depth after eight years different management of second generation hybrid aspen. Mean values ( $n=4$ where each $n$ consisted of three subsamples), standard errors (Std.err.) and $p$-values for treatment means are shown.

\begin{tabular}{lcccccc}
\hline \multirow{2}{*}{$\begin{array}{l}\text { Management } \\
\text { regime }\end{array}$} & \multicolumn{2}{c}{$\begin{array}{c}\text { Fine earth } \\
\left(\mathrm{g} \mathrm{cm}^{-3}\right)\end{array}$} & \multicolumn{2}{c}{$\begin{array}{c}\text { Gravel relative } \\
\text { volume }(\%)\end{array}$} & \multicolumn{2}{c}{$\begin{array}{c}\text { Organic } \\
\left(\mathrm{g} \mathrm{cm}^{-3}\right)\end{array}$} \\
\cline { 2 - 7 } & Mean & Std.err. & Mean & Std.err. & Mean & Std.err. \\
\hline 4YR & 1.12 & 0.03 & 2.65 & 0.63 & 0.0032 & 0.0014 \\
8YR & 1.18 & 0.05 & 1.98 & 0.40 & 0.0066 & 0.0025 \\
8+YR & 1.20 & 0.06 & 1.36 & 0.24 & 0.0032 & 0.0006 \\
\hline p-value & 0.491 & - & 0.162 & - & 0.200 & - \\
\hline
\end{tabular}

Tab. 6 - Soil pools ( $M g$ ha ${ }^{-1}$ to $30 \mathrm{~cm}$ depth) of SOC and Tot N, CN-ratio, $\mathrm{NH}_{4}-\mathrm{N}, \mathrm{NO}_{3}-\mathrm{N}, \mathrm{P}$ and base cations ( $\mathrm{K}, \mathrm{Ca}, \mathrm{Mg}$ ) after eight years different management of second generation hybrid aspen. Mean values ( $n=4$, each $n$ consisting of 20 subsamples), standard errors (Std.err.) and $p$-values for treatment means are shown.

\begin{tabular}{|c|c|c|c|c|c|}
\hline \multirow{2}{*}{$\begin{array}{l}\text { Element } \\
\left(\mathrm{Mg} \mathrm{ha}^{-1}\right)\end{array}$} & \multirow{2}{*}{ Stats } & \multicolumn{3}{|c|}{ Management regime } & \multirow{2}{*}{$\mathrm{p}$-value } \\
\hline & & 4YR & $8 Y R$ & $8+Y R$ & \\
\hline \multirow[t]{2}{*}{ SOC } & Mean & 64.70 & 54.80 & 65.90 & 0.095 \\
\hline & Std.err. & 6.30 & 5.42 & 4.62 & - \\
\hline \multirow[t]{2}{*}{ Tot $N$} & Mean & 5.35 & 4.47 & 5.44 & 0.375 \\
\hline & Std.err. & 0.63 & 0.40 & 0.49 & - \\
\hline \multirow[t]{2}{*}{$\mathrm{CN}$} & Mean & 12.20 & 12.30 & 12.20 & 0.404 \\
\hline & Std.err. & 0.52 & 0.49 & 0.29 & - \\
\hline \multirow[t]{2}{*}{$\mathrm{NH}_{4}-\mathrm{N}$} & Mean & 0.0217 & 0.0272 & 0.0305 & 0.997 \\
\hline & Std.err. & 0.0013 & 0.0013 & 0.0023 & - \\
\hline \multirow[t]{2}{*}{$\mathrm{NO}_{3}-\mathrm{N}$} & Mean & 0.0119 & 0.0057 & 0.0082 & 0.342 \\
\hline & Std.err. & 0.0019 & 0.001 & 0.0019 & - \\
\hline \multirow[t]{2}{*}{$P$} & Mean & 0.500 & 0.570 & 0.477 & 0.673 \\
\hline & Std.err. & 0.018 & 0.064 & 0.096 & - \\
\hline \multirow[t]{2}{*}{$\mathrm{K}$} & Mean & 0.417 & 0.437 & 0.489 & 0.683 \\
\hline & Std.err. & 0.05 & 0.043 & 0.058 & - \\
\hline \multirow[t]{2}{*}{$\mathrm{Ca}$} & Mean & 5.64 & 3.45 & 4.83 & 0.919 \\
\hline & Std.err. & 1.24 & 1.11 & 0.78 & - \\
\hline \multirow[t]{2}{*}{$M g$} & Mean & 0.517 & 0.497 & 0.615 & 0.799 \\
\hline & Std.err. & 0.057 & 0.108 & 0.091 & - \\
\hline
\end{tabular}

vested stems influenced the amounts removed nutrients (Fig. 1). Removed quantities of $\mathrm{N}$ were largest for the lower diameter shoots and would accordingly affect the 4 YR regime most (Fig. 1, Tab. 3). However, Tot $\mathrm{N}$ soil concentrations (Fig. $2 \mathrm{~b}$, Tab. 4) and pools (Tab. 6) of the 4YR regime did not differ from those of the other regimes after two complete rotations (hypothesis 2). There was no productivity decline observed in the two consecutive 4-year rotations, which suggests that there was no shortage of $\mathrm{N}$ (Rytter \& Rytter 2017). The $C N$ ratios were similar, i.e., around 12 based on amounts $\left(\mathrm{Mg} \mathrm{ha}^{-1}\right)$, in all management regimes (Tab. 6). These $\mathrm{CN}$ ratios were of the same magnitude as those measured in a comprehensive study of Swedish arable soils, containing 2034 sampling points across Sweden with a mean CN ratio of 11 (Eriksson et al. 2010). Thus, the soil fertility in our studied plantation was in the same range as fertile arable soils almost 20 years after afforestation with hybrid aspen. Increasing ratios will be expected upon afforestation due to the input of forest litter with higher $\mathrm{CN}$ ratios compared to annual crops, uptake of inorganic $\mathrm{N}$ and cessation of $\mathrm{N}$-fertilization (Jug et al. 1999, Rosenqvist et al. 2010), but the effect of annual crop cultivation could remain for 30 years or even longer (Koerner et al. 1997, Ritter et al. 2003).

Decreases in $\mathrm{pH}$ may be expected upon afforestation (Jug et al. 1999, Ritter et al. 2003, Lutter et al. 2016a, Rytter 2016). Swedish arable soils had a mean $\mathrm{pH}$ of 6.3 (Eriksson et al. 2010) which is somewhat higher than the $\mathrm{pH}$ measured in our plantation, i.e., $5.5-5.8$ at the latter sampling. However, we found no significant time effect on soil $\mathrm{pH}$ during our study interval and no differences caused by management regime (Fig. 3a, Tab. 4).

Ammonium is released by the mineralization process and is an important form of $\mathrm{N}$ utilized by plants. The significant increase in the top $15 \mathrm{~cm}$ mineral soil in all management regimes can thus be explained by enhanced uptake of $\mathrm{NH}_{4}-\mathrm{N}$ by fast-growing 
hybrid aspen from deeper horizons and recirculation by decomposing litter at the surface (Fig. 3b, Tab. 4). It is by now wellknown that tree species influence the size of the nutrient pools and the distribution among soil horizons (Binkley 1995). It can also be concluded from the increased or unchanged concentrations in both investigated soil depths in the present study that the rate of $\mathrm{N}$ uptake did not exceed the rate of mineralization in these layers. The effect on $\mathrm{NO}_{3}-\mathrm{N}$ concentrations was the opposite, i.e., a declining trend in all regimes (Fig. 3b, Tab. 4). This could be an indication of leakage of the ion. However, an analysis of vertical distribution of nutrients in soils found an extremely variable distribution for $\mathrm{NO}_{3}-\mathrm{N}$ which makes interpretations difficult (Jobbágy \& Jackson 2001).

Afforestation of cropland may lead to decreases in $\mathrm{P}$ concentrations and $\mathrm{P}$ pools in the upper mineral soil according to a metaanalysis (Deng et al. 2017). However, we found that the plant available $P$ concentrations were in the range of $120-180 \mathrm{mg} \mathrm{kg}^{-1}$, including both soil depths and all management regimes (Fig. 4, Tab. 4), which was higher than the mean concentrations of 80 $\mathrm{mg} \mathrm{kg}{ }^{-1}$ estimated for Swedish arable soils (ammonium lactate-acetate extracted Eriksson et al. 2010). Thus, there were apparently no depletion of plant available $P$ and the concentrations remained stable during the studied period.

Base cation concentrations and pools in the mineral soil did not differ between management regimes, but general decreases in concentrations in the deeper soil layer and increases in the shallower layer were observed for $\mathrm{K}$ and $\mathrm{Mg}$, but not for Ca (Fig. 4, Tab. 4, Tab. 5). This implies a plant mediated redistribution of $\mathrm{K}$ and $\mathrm{Mg}$ by plant uptake in deeper soil and release through litter decomposition at the surface which has also been suggested in earlier studies (Alban 1982, Jobbágy \& Jackson 2001, Rytter 2016). Calcium is important for regulation and development of plant growth as well as in soil buffering systems. It was the most abundant cation found in the soil in the present study (Tab. 6), but it showed also the largest removal figures (Tab. 3). However, $\mathrm{Ca}$ is required in small amounts in plants (Hepler 2005) and the concentrations measured were stable over time (Fig. 4).

An estimate of bulk density is important for assessing the size of nutrient pools in soils. Soil bulk density could be affected by compaction, activity of soil organisms, presence of roots and soil organic material (Bronick \& Lal 2005). Differences in bulk density between management regimes in the present study may be expected due to various intensity in harvests and thinning measures and different stand densities. This will cause differences in the supply of above ground litter, the density of roots and root litter supply, soil temperature and humidity which together probably will cause differences in the amounts of SOC.
However, no statistically significant differences in bulk density between the regimes were observed so far (Tab. 5).

\section{Conclusions}

The different management regimes in root-sucker generated hybrid aspen resulted in few significant effects on mineral soil characteristics (hypothesis 1), despite large variations in removed quantities of biomass and nutrients (hypothesis 2). The only exception was a slightly lower SOC concentration in the $8 \mathrm{YR}$ regime. Thus, it can be concluded that the management measures with various harvesting and thinning intensities did not influence soil characteristics differently during the first eight years after initiation. It is however important to follow the development of soil characteristics in these plantations during several rotations since short rotation forestry with hybrid aspen is a comparatively new silvicultural approach and the long-term impact on soil properties is unclear.

Common for all management regimes were the unchanged $\mathrm{SOC}$ and nutrient pools in the upper $30 \mathrm{~cm}$ mineral soil. $\mathrm{pH}$ and bulk density were also unaffected during the studied period. Afforestation effects on the vertical distribution of nutrients, i.e., redistribution of $\mathrm{NH}_{4}-\mathrm{N}, \mathrm{K}$ and $\mathrm{Mg}$ from deeper to shallower soil by plant uptake and release through litter decomposition, were observed in all management regimes. A different effect was noted for $\mathrm{NO}_{3}-\mathrm{N}$ where a declining trend was observed in both the investigated soil depths. This could indicate a leakage of the ion, but $\mathrm{NO}_{3}-\mathrm{N}$ distributions in soils are variable which makes interpretations difficult.

\section{Acknowledgements}

The authors wish to thank Frosten Nilsson and Fredrika Rytter for their help with the soil sampling, as well as the personnel at the Ekebo research station of the Forestry Institute of Sweden for processing the wood samples. We are also grateful for valuable comments on the manuscript from three anonymous reviewers. The study was financially jointly supported by the Swedish Energy Agency, the frame program of the Forestry Research Institute of Sweden and Rytter Science.

\section{References}

Atterberg A (1905). Die rationale Klassifikation der Sande und Kiese. [The rational classification of sand and gravel]. Chemiker-Zeitung 29: 195-198.

AgroEcoLab@UMD (2018). Mehlich 3 extraction protocol. University of Maryland, College Park, MD, USA, Web Site. [online] URL: http://www. agroecologylab.com/uploads/2/7/2/8/27281831/ mehlich3_extraction.pdf

Alban DH (1982). Effects of nutrient accumulation by aspen, spruce, and pine on soil properties. Soil Science Society of America Journal 46: 853-861. - doi: 10.2136/sssaj1982.036159950046 $00040037 x$
Anonymous (2012). Improving lives with poplars and willows. In: "Synthesis of Country Progress Reports". International Poplar Commission, 24th session, Dehradun (India) 30 Oct-2 Nov 2012. Working Paper IPC/12E, FAO, Rome, Italy, pp. 93.

Arevalo CBM, Bhatti JS, Chang SX, Sidders D (2011). Land use change effects on ecosystem carbon balance: from agricultural to hybrid poplar plantation. Agriculture, Ecosystems and Environment 141: 342-349. - doi: 10.1016/j.agee. 2011.03.013

Binkley D (1995). The influence of tree species on forest soils: processes and patterns. In: Proceedings of the "Trees and Soil Workshop" (Mead DJ, Cornforth IS eds). Lincoln University, Agronomy Society of New Zealand, Special Publication no. 10, Lincoln University Press, Canterbury, New Zealand, pp. 1-33.

Bronick CJ, Lal R (2005). Soil structure and management, a review. Geoderma 124: 3-22. - doi: 10.1016/j.geoderma.2004.03.005

Deng Q, McMahon DE, Xiang Y, Yu C-L, Jackson RB, Hui D (2017). A global meta-analysis of soil phosphorus dynamics after afforestation. New Phytologist 213: 181-192. - doi: 10.1111/nph.14119 Eriksson J, Andersson A, Andersson R (1999). Texture of agricultural topsoils in Sweden. Report no. 4955, Naturvårdsverket, Stockholm, Sweden, pp. 48. [In Swedish with English summary]

Eriksson J, Mattsson L, Söderström M (2010). Current status of Swedish arable soils and cereal crops. Data from the period 2001-2007. Naturvårdsverket, Stockholm, Sweden, pp. 129. [In Swedish with English summary]

FAO (2006). Guidelines for soil description. Soil Resources Development and Conservation Service, Land and Water Development Division, FAO, Rome, Italy, pp. 98.

Grigal DF, Berguson WE (1998). Soil carbon changes associated with short-rotation systems. Biomass and Bioenergy 14: 371-377. - doi: 10.1016/So961-9534(97)10073-3

Hansen EA (1993). Soil carbon sequestration beneath hybrid poplar plantations in the North Central United States. Biomass and Bioenergy 5: 431-436. - doi: 10.1016/0961-9534(93)90038-6 Hedenus F, Azar C (2009). Bioenergy plantations or long-term carbon sinks? A model based analysis. Biomass and Bioenergy 33: 1693-1702. - doi: 10.1016/j.biombioe.2009.09.003

Hepler PK (2005). Calcium: a central regulator of plant growth and development. The Plant Cell 17: 2142-2155. - doi: 10.1105/tpc.105.032508

Jandl $R$, Lindner $M$, Vesterdal L, Bauwens $B$, Baritz R, Hagedorn F, Johnson DW, Minkkinen K, Byrne KA (2007). How strongly can forest management influence soil carbon sequestration? Geoderma 137: 253-268. - doi: 10.1016/j.geoder ma.2006.09.003

Jobbágy EG, Jackson RB (2001). The distribution of soil nutrients with depth: global patterns and the imprint of plants. Biogeochemistry 53: 51-77. - doi: 10.1023/A:1010760720215

Johansson T (2013). Biomass production of hybrid aspen growing on former farm land in Sweden. Journal of Forestry Research 24: 237246. - doi: 10.1007/s11676-012-0305-X

Johnson DW, Curtis PS (2001). Effects of forest management on soil $\mathrm{C}$ and $\mathrm{N}$ storage: meta 
analysis. Forest Ecology and Management 140: 227-238. - doi: 10.1016/S0378-1127(00)00282-6

Jug A, Makeschin F, Rehfuess KE, HofmannSchielle C (1999). Short-rotation plantations of balsam poplars, aspen and willows on former arable land in the Federal Republic of Germany. III. Soil ecological effects. Forest Ecology and Management 121: 85-99. - doi: 10.1016/S03781127(98)00558-1

Jurgensen M, Tarpey R, Pickens J, Kolka R, Palik $B$ (2012). Long-term effect of silvicultural thinnings on soil carbon and nitrogen pools. Soil Science Society of America Journal 76: 14181425. - doi: 10.2136/sssaj2011.0257

Koerner W, Dupouey JL, Dambrine E, Benoît M (1997). Influence of past land use on the vegetation and soils of present day forest in the Vosges mountains, France. Journal of Ecology 85:351-358. - doi: 10.2307/2960507

Lal R (2008). Carbon sequestration. Philosophical Transactions of the Royal Society B 363: 815830. - doi: 10.1098/rstb.2007.2185

Liesebach M, Von Wuehlisch G, Muhs H-J (1999). Aspen for short-rotation coppice plantations on agricultural sites in Germany: effects of spacing and rotation time on growth and biomass production of aspen progenies. Forest Ecology and Management 121: 25-39. - doi: 10.1016/S0378-1127(98)00554-4

Lutter R, Tullus A, Kanal A, Tullus T, Tullus H (2016a). The impact of former land-use type to above- and below-ground $\mathrm{C}$ and $\mathrm{N}$ pools in short-rotation hybrid aspen (Populus tremula L. $\times$ P. tremuloides Michx.) plantations in hemiboreal conditions. Forest Ecology and Management 378: 79-90. - doi: 10.1016/j.foreco.2016.07 . 021

Lutter R, Tullus A, Kanal A, Tullus T, Tullus $\mathrm{H}$ (2016b). The impact of short-rotation hybrid aspen (Populus tremula L. $\times$ P. tremuloides Michx.) plantations on nutritional status of former arable soils. Forest Ecology and Management 362: 184-193. - doi: 10.1016/j.foreco.2015.12.009 McCarthy R, Rytter L (2015). Productivity and thinning effects in hybrid aspen root sucker stands. Forest Ecology and Management 354: 215-223. - doi: 10.1016/j.foreco.2015.06.015

McNabb DH, Cromack K, Fredriksen RL (1986). Variability of nitrogen and carbon in surface soils of six forest types in the Oregon Cascades. Soil Science Society of America Journal 50: 1037-1041. - doi: 10.2136/sssaj1986.036159950 05000040040x

Nave LE, Vance ED, Swanston CW, Curtis PS (2010). Harvest impacts on soil carbon storage in temperate forests. Forest Ecology and Management 259: 857-866. - doi: 10.1016/j.foreco. 2009.12.009

Nilsen P, Strand T (2008). Thinning intensity effects on carbon and nitrogen stores and fluxes in a Norway spruce (Picea abies (L.) Karst.) stand after 33 years. Forest Ecology and Management 256: 201-208. - doi: 10.1016/j.foreco. 2008.04.001

Olesen PO (1971). The water displacement method - A fast and accurate method of determining the green volume of wood samples. Arboretet Hørsholm, Akademisk Forlag, København, Denmark. Forest Tree Improvement 3: 3-23.

R Core Team (2017). R: a language and environment for statistical computing. R Foundation for Statistical Computing, Vienna, Austria. [online] URL: http://www.r-project.org/

Ritter E, Vesterdal L, Gundersen P (2003). Changes in soil properties at afforestation of former intensively managed soils with oak and Norway spruce. Plant and Soil 249: 319-330. doi: 10.1023/A:1022808410732

Rosenberg O, Jacobson S (2004). Effects of repeated slash removal in thinned stands on soil chemistry and understorey vegetation. Silva Fennica 38 (2): 133-142. - doi: 10.14214/sf.423 Rosenqvist L, Kleja DB, Johansson M-B (2010). Concentrations and fluxes of dissolved organic carbon and nitrogen in a Picea abies chronosequence on former arable land in Sweden. Forest Ecology and Management 259: 275-285. doi: 10.1016/j.foreco.2009.10.013

Rytter L (2002). Nutrient content in stems of hybrid aspen as affected by tree age and tree size, and nutrient removal with harvest. Biomass and Bioenergy 23: 13-25. - doi: 10.1016/So9 61-9534(02)00029-6

Rytter L, Johansson T, Karačić A, Weih M (2011). Orienterande studie om ett svenskt forskningsprogram för poppel. [Investigation for a Swedish research program on the genus Populus]. Skogforsk, Arbetsrapport no. 733, Uppsala, Sweden, pp. 148. [In Swedish with English summary]

Rytter L, Johansson K, Karlsson B, Stener L-C (2013). Tree species, genetics and regeneration for bioenergy feedstock in northern Europe. In: “Forest BioEnergy Production” (Kellomäki S,
Kilpeläinen A, Alam A eds). Springer Science+ Business Media, New York, USA, pp. 7-37. - doi: 10.1007/978-1-4614-8391-5_2

Rytter L, Rytter R-M (2017). Productivity and sustainability of hybrid aspen (Populus tremula L. $x$ $P$. tremuloides Michx.) root sucker stands with varying management strategies. Forest Ecology and Management 401: 223-232. - doi: 10.101 6/j.foreco.2017.07.020

Rytter R-M (2012a). The potential of willow and poplar plantations as carbon sinks in Sweden. Biomass and Bioenergy 36: 86-95. - doi: 10.1016/ j.biombioe.2011.10.012

Rytter R-M (2012b). Stone and gravel content of arable soils influence estimates of $\mathrm{C}$ and $\mathrm{N}$ stocks. Catena 95: 153-159. - doi: 10.1016/j.cate na.2012.02.015

Rytter R-M (2016). Afforestation of former agricultural land with Salicaceae species - initial effects on soil organic carbon, mineral nutrients, $\mathrm{C}: \mathrm{N}$ and $\mathrm{pH}$. Forest Ecology and Management 363: 21-30. - doi: 10.1016/j.foreco.2015.12.026

SMHI (2018a). Klimatindikator - vegetationsperiodens längd [Climate indicator - Length of vegetation]. Swedish Meteorological and Hydrological Institute, Norrköping, Sweden, Web site. [in Swedish] [online] URL: http://www. smhi.se/kunskapsbanken/klimat/klimatindikato r-vegetationsperiodens-langd-1.7887

SMHI (2018b). Dataserier med normalvärden för perioden 1961-1990 [Data series with normal values for the period 1961-1990]. Swedish Meteorological and Hydrological Institute, Norrköping, Sweden, Web site. [in Swedish] [online] URL: http://www.smhi.se/klimatdata/me teorologi/dataserier-med-normalvarden-1.7354 Telenius BF (1999). Stand growth of deciduous pioneer tree species on fertile agricultural land in southern Sweden. Biomass and Bioenergy 16: 13-23. - doi: 10.1016/S0961-9534(98)00073-7 Tullus A, Rytter L, Tullus $T$, Weih $M$, Tullus $H$ (2012). Short-rotation forestry with hybrid aspen (Populus tremula L. $\times$ P. tremuloides Michx.) in Northern Europe. Scandinavian Journal of Forest Research 27: 10-29. - doi: 10.1080/0282 7581.2011.628949

White RE (2006). Principles and practice of soil science - The soil as a natural resource $\left(4^{\text {th }}\right.$ edn $)$. Wiley-Blackwell Publishing, Oxford, UK, pp. 376. 